\title{
Determination of Self Efficacy Perception Levels of Teachers' Attending an Online Course toward Web Pedagogical Content Knowledge
}

\author{
Özge Özyalçın Oskay ${ }^{*}$, Zuhal Odabaşı \\ Department of Chemistry Education, Faculty of Education, Hacettepe University, Turkey
}

Copyright $(2016$ by authors, all rights reserved. Authors agree that this article remains permanently open access under the terms of the Creative Commons Attribution License 4.0 International License

\begin{abstract}
The effects of technological developments occurred new requirements in educational area. Today's teachers should know the content knowledge they teach, have pedagogical knowledge about teaching and learning methods and besides should use the technological tools effectively. Depending on these, new concepts such as Technological Pedagogical Content Knowledge, Web Pedagogical Content Knowledge occurred. With this study it was aimed to determine self-efficacy perception levels of 250 teachers attending an online chemistry course preparing teachers for an examination to be a teacher in the public schools named as KPSS (Public Personnel Examination), toward web pedagogical content knowledge. Web Pedagogical Content Knowledge Scale developed by Lee, Tsai and Chang [1] and adapted to Turkish by Horzum [2] was used as data collection tool.
\end{abstract}

Keywords Web Pedagogical Content Knowledge Scale, Online Chemistry Course, Self-efficacy Perception Levels toward Web Pedagogical Content Knowledge

\section{Introduction}

It is inevitable in the 21 st century that the structure of education to be offered to, and the materials used with the young generation - who use technology in every field of their lives and whose lifestyle also changes in a sense- will be modified and be renewed. While effective education and teachers' efficacies necessary for preparing an efficient classroom environment involved only pedagogical knowledge, domain knowledge and pedagogical domain knowledge twenty years ago, the concepts of technological knowledge and technological pedagogical content knowledge are discussed today.

Today's teachers should both have knowledge of and the ability to use technological vehicles and know how to integrate them into their lessons. Teachers can use digital stories, computer games, videos, animations, educational software, digital case studies, multimedia simulations, applications in mobile communication instruments, blogs, social media and web research studies in their classes effectively [3].

One of the most effective instruments teachers can employ in designing technology-based class environments is the internet. Limitless accessibility to the source, providing opportunities for interpersonal interaction, its ability to offer service independent of time and place have all made the internet a preferable instrument. The rapid development of web technologies have made materials for distance education more flexible and thus led to changes to make such settings an alternative to or a support to education in traditional classrooms [4]. Teachers can design classes supported by graphs, audio materials, animations, videos and texts in internet-based or interned-assisted classes [5]. These possibilities provided by the internet require that teachers and prospective teachers have the knowledge of and skills in using the internet and internet technologies in instruction [2].

Due to the fact that the properties of the internet/web were different from other technologies, that using them needed technology, and that technological pedagogical domain knowledge did not provide adequate knowledge; Lee and Tsai [5] and Lee, Tsai and Chang [6] described the concept of Web Pedagogical Content Knowledge (WPCK).

The WPCK has four components. Namely; pedagogical content knowledge: It is the knowledge related to effective methods of teaching for use in teaching a topic of domain. It is also the effective transfer of that knowledge [7]. Web pedagogical knowledge: It stresses the availability of web used by teachers in educational environments as well as the components of it and teachers' capabilities. Teachers need to know what pedagogical strategies to use along with the web in order to yield the most effective results besides knowing a series of web tools for a certain task [5]. Web content knowledge: It means combining the content of a topic with the properties and advantages of web. It expresses not only teaching the content but also teachers' knowledge of 
integrating the content into the medium of web. Web pedagogical content knowledge: It expresses teaching by using the web, both teaching the content and integrating the web properties into the content [5]. The most important criterion determining teachers' effective and successful use of technology in their classes is their pedagogical and personal beliefs [8]. According to Lee and Tsai [5], teachers' perception of teaching with technology and web/internet is influential in the quality of their lessons. Therefore, determining prospective teachers' perceptions of self-efficacy in teaching with the internet is very important for teachers' and prospective teachers' professional development.

Barış [15] analyzed the Technological Pedagogical Content Knowledge and Educational Use of Web Technologies (TPCK-W) in addition to the self-efficacy and attitudes of 33 teachers from eight different branches from 19 countries of the European Union (EU). As a result of the analysis, it was revealed that TPCK-W self-efficacy of teachers carrying out their duties in EU countries was high and their attitudes were positive; and age, experience, and gender did not affect their TPCK-W self-efficacy and attitudes. Moreover, participants' general web attitudes changed positively, depending on their web communication, web content, and pedagogical use of the web.

In his study which was conducted with 29 university students, Horzum [16] aimed to determine the effect of web based instruction on students' web pedagogical content knowledge, academic achievement and the general satisfaction of the course.

The study was planned and completed according to pre-test and post-test with control group experimental design. The web content knowledge of the students in both group showed significant change after the experimental procedure. The web pedagogical content knowledge and the attitudes towards web based instruction of the experiment group were found to be higher than control group after the course. Also the academic achievement of experiment group was higher than control group and there was no difference in course satisfaction.

\section{Materials and Methods}

\subsection{Aim of the Study}

This study aimed to determine the levels of self-efficacy in web content knowledge of prospective teachers taking the chemistry course in an online private school preparing prospective teachers for KPSS (Public Personnel Selection Examination). In line with this purpose, the sub-problems for the study are as in the following:

1. At what levels are prospective teachers in terms of general web content knowledge, communicative web knowledge, pedagogical web knowledge and web pedagogical content knowledge - which are the sub-dimensions of the scale for Web Pedagogical Content Knowledge?

2. At what levels are prospective teachers in terms of attitudes towards web-based teaching?

3. Do the levels of perception of self-efficacy in general web content knowledge; communicative web knowledge, pedagogical web knowledge and web pedagogical content knowledge - which are the sub-dimensions of the scale for Web Pedagogical Content Knowledge - differ according to gender?

4. Do the levels of perception of self-efficacy in general web content knowledge, communicative web knowledge, pedagogical web knowledge and web pedagogical content knowledge - which are the sub-dimensions of the scale for Web Pedagogical Content Knowledge - differ according to the school prospective teachers attend or have graduated from?

\subsection{Sample of the Study}

The research sample was composed of 250 prospective teachers attending an online KPSS (Public Personnel Examination) preparation course and taking a chemistry course 189 of whom were female and 61 of whom were male students. 120 of the prospective teachers in the sample were graduates of the chemistry teaching department whereas 130 of them were graduates of the science and technology teaching department.

\subsection{Data Collection Tools}

"Web Pedagogical Content Knowledge Scale", which was developed by Lee and Tsai [5] and was adapted into Turkish and validated by Horzum was used as the tool of data collection in this research. Cronbach alpha coefficient was found to be .94 [2]. The Web Pedagogical Content Knowledge Scale contained 30 items and had five factors called general web content knowledge $(\alpha=0.88)$, communicative web content knowledge $(\alpha=0.91)$, pedagogical web content knowledge $(\alpha=0.95)$, web pedagogical content knowledge $(\alpha=0.90)$, and attitudes towards web-based teaching $(\alpha=0.92)$. The scale was scored in five points changing between "I absolutely disagree" and "I absolutely agree". The scores receivable from the scale were between 30 at the minimum and 150 at the maximum.

\subsection{Stages of Application}

The Web Pedagogical Content Knowledge Scale was applied to prospective teachers doing an online KPSS course in Ankara in 2015-2016 academic year. In Turkey, in order to be a teacher in public schools, pre-service teachers must have higher scores from KPSS examination. One of the parts of the examination is basic chemistry. The prospective teachers participating in the research took the basic chemistry lessons online supported by animations, and they 
watched the course videos whenever they wished for the asynchronic dimension of the course. The participants completed the scale online.

\section{Findings}

Table 1 shows the averages and standard deviations for the prospective teachers' views of the sub-dimensions of Web Pedagogical Content Knowledge.

Table 1. Prospective teachers' views of the sub-dimensions of Web Pedagogical Content Knowledge

\begin{tabular}{|c|c|c|}
\hline $\begin{array}{c}\text { Sub-dimensions of Web Pedagogical } \\
\text { Content Knowledge }\end{array}$ & X & ss \\
\hline Web-General & 4,63 & 0,63 \\
\hline Web-Communicative & 4,52 & 0,79 \\
\hline Web Pedagogical Knowledge & 4,52 & 0,79 \\
\hline Web Pedagogical Content Knowledge & 4,62 & 0,63 \\
\hline Attitudes towards Web-based Teaching & 4,65 & 0,57 \\
\hline
\end{tabular}

According to Table 1, prospective teachers had quite high levels of perception $(X=4,63)$ in terms of being able to click on a bridge to connect to a web page, being able to enter the address of a web site, being able to printout the web site content, being able to use the key words for searching on the web, being able to download pictures, being able to use search engines on the web, and being able to copy texts onto the word programme on the sub-dimension of "general web".

They had quite high levels of perception $(X=4,52)$ in terms of being able to use the internet sources in the lesson content, being able to select appropriable content from web sources, being able to search for materials online, and being able to search for materials on the web on the sub-dimension of "pedagogical web" -that is to say, in terms of knowledge that web technology could be used for enriching lessons.

They had quite high levels of perception $(X=4,62)$ on the sub-dimension of "web pedagogical content" - that is to say, in terms of using the teaching modules available on the web in classes, using the web technologies in order to develop multiple teaching strategies, acting as a guide to students in using the web sources for a certain course unit, and using the web technologies to support teaching for the content of a course unit.

They had quite high levels of perception $(X=4,65)$ on the sub-dimension of " attitudes towards web-based teaching" that is to say, in using the web technologies in real teaching and in the fact that web supported teaching, that web could develop teaching skills, and that it could develop learning motivation.

Table 2 shows prospective teachers' independent sample t-test results for the sub-dimensions of the Web Pedagogical Content Knowledge scale according to gender.
Table 2. Independent sample t-test results for the sub-dimensions of the Web Pedagogical Content Knowledge scale

\begin{tabular}{|c|c|c|c|c|c|c|}
\hline $\begin{array}{c}\text { WPCK } \\
\text { Sub-dimensions }\end{array}$ & Gender & $\mathrm{N}$ & $\mathrm{X}$ & Ss & $\mathrm{t}$ & $\mathrm{p}$ \\
\hline \multirow{2}{*}{$\begin{array}{c}\text { Web-General } \\
\text { Web-Communicative }\end{array}$} & Female & 189 & 4,64 & ,63 & \multirow{2}{*}{0,22} & \multirow{2}{*}{0,83} \\
\hline & Male & 61 & 4,6 &, 64 & & \\
\hline \multirow{2}{*}{$\begin{array}{c}\text { Web Pedagogical } \\
\text { Knowledge } \\
\text { Web Pedagogical } \\
\text { Content Knowledge }\end{array}$} & Female & 189 & 4,52 &, 79 & \multirow[b]{2}{*}{$-0,00$} & \multirow[b]{2}{*}{0,99} \\
\hline & Male & 61 & 4,52 & ,82 & & \\
\hline \multirow{2}{*}{$\begin{array}{c}\text { Attitudes towards } \\
\text { Web-based Teaching } \\
\text { Web-General }\end{array}$} & Female & 189 & 4,74 &, 54 & \multirow{2}{*}{0,54} & \multirow{2}{*}{0,59} \\
\hline & Male & 61 & 4,70 &, 57 & & \\
\hline \multirow{2}{*}{$\begin{array}{c}\text { Web-Communicative } \\
\text { Web Pedagogical } \\
\text { Knowledge }\end{array}$} & Female & 189 & 4,62 & ,64 & \multirow{2}{*}{$-0,20$} & \multirow{2}{*}{0,84} \\
\hline & Male & 61 & 4,64 &, 61 & & \\
\hline \multirow{2}{*}{$\begin{array}{l}\text { Web Pedagogical } \\
\text { Content Knowledge }\end{array}$} & Female & 189 & 4,64 &, 58 & \multirow{2}{*}{$-0,30$} & \multirow{2}{*}{0,76} \\
\hline & Male & 61 & 4,67 &, 55 & & \\
\hline
\end{tabular}

No significant differences were found in male and female students' levels of perception in terms of the sub-dimensions of the Web Pedagogical Content Knowledge scale according to gender $(\mathrm{p}>0.05)$.

Table 3. Prospective Teachers' Independent Sample t-test Results for the Sub-dimensions of the Web Pedagogical Content Knowledge according to Their Departments

\begin{tabular}{|c|c|c|c|c|c|c|}
\hline $\begin{array}{c}\text { WPCK } \\
\text { Sub-dimensions }\end{array}$ & Department & $\mathrm{N}$ & X & Ss & $\mathrm{t}$ & $\mathrm{p}$ \\
\hline \multirow{2}{*}{ Web-General } & $\begin{array}{l}\text { Chemistry } \\
\text { Educ. }\end{array}$ & 120 & 4,52 & ,69 & \multirow{2}{*}{$-2,83$} & \multirow{2}{*}{0,005} \\
\hline & $\begin{array}{c}\text { Science and } \\
\text { Tech.Dept. }\end{array}$ & 130 & 4,75 &, 55 & & \\
\hline \multirow{2}{*}{$\begin{array}{c}\text { Web- } \\
\text { Communicative }\end{array}$} & $\begin{array}{c}\text { Chemistry } \\
\text { Educ. }\end{array}$ & 120 & 4,35 &, 87 & \multirow{2}{*}{$-3,40$} & \multirow{2}{*}{0,001} \\
\hline & $\begin{array}{c}\text { Science and } \\
\text { Tech.Dept. }\end{array}$ & 130 & 4,68 & ,68 & & \\
\hline \multirow{2}{*}{$\begin{array}{c}\text { Web } \\
\text { Pedagogical } \\
\text { Knowledge }\end{array}$} & $\begin{array}{l}\text { Chemistry } \\
\text { Educ. }\end{array}$ & 120 & 4,62 & ,61 & \multirow{2}{*}{$-3,06$} & \multirow{2}{*}{0,002} \\
\hline & $\begin{array}{c}\text { Science and } \\
\text { Tech.Dept. }\end{array}$ & 130 & 4,83 & ,45 & & \\
\hline \multirow{2}{*}{$\begin{array}{c}\text { Web } \\
\text { Pedagogical } \\
\text { Content } \\
\text { Knowledge }\end{array}$} & $\begin{array}{l}\text { Chemistry } \\
\text { Educ. }\end{array}$ & 120 & 4,49 & ,69 & \multirow{2}{*}{$-3,1$} & \multirow{2}{*}{0,002} \\
\hline & $\begin{array}{c}\text { Science and } \\
\text { Tech.Dept. }\end{array}$ & 130 & 4,74 &, 55 & & \\
\hline \multirow{2}{*}{$\begin{array}{l}\text { Attitudes } \\
\text { towards } \\
\text { Web-based } \\
\text { Teaching }\end{array}$} & $\begin{array}{c}\text { Chemistry } \\
\text { Educ. }\end{array}$ & 120 & 4,53 & ,63 & \multirow{2}{*}{$-3,62$} & \multirow{2}{*}{0,001} \\
\hline & $\begin{array}{c}\text { Science and } \\
\text { Tech.Dept. }\end{array}$ & 130 & 4,76 & ,49 & & \\
\hline
\end{tabular}

Significant differences were found in favor of the students of science and technology teaching department on all sub-dimensions of the Web Pedagogical Content Knowledge scale. Accordingly: General web (X chemistry $=4,52, X$ science and techn.. $=4,75 \mathrm{p}<0.05$ ), communicative web ( $\mathrm{X}$ chemistry $=4,35, X$ science and techn.. $=4,68 \mathrm{p}<0.05$ ), pedagogical web (X chemistry $=4,62, X$ science and techn.. $=4,83 \quad \mathrm{p}<0.05)$, web pedagogical content (X chemistry $=4,49, X$ science and techn.. $=4,73 \mathrm{p}<0.05)$, and attitudes towards web-based teaching ( $\mathrm{X}$ chemistry $=4,52, \mathrm{X}$ science and techn.. $=4,76 \mathrm{p}<0.05$ ). 


\section{Conclusions and Discussion}

This study, which determined the perception levels of self-efficacy in web content knowledge of prospective teachers taking a chemistry course in an online private school, found that prospective teachers had quite high levels of self-efficacy $(X>4.50)$ on all sub-dimensions of the scale. The reason for this might be that the participants were attending a distance education programme, that they could use technology actively during their education, and that they understood the importance of it.

On analyzing prospective teachers' perception levels of self-efficacy according to gender, no statistically significant differences were found between male and female students. In a similar vein, Akgün [9] found no significant differences between prospective teachers' web pedagogical domain knowledge in terms of gender, and Kazu and Erten [10] found that pedagogical content knowledge did not differ according to gender in their study entitled "Prospective Elementary School Teachers' Views on Web Pedagogical Content Knowledge", for which the researchers consulted to participants' views. Gömleksiz and Fidan [11], in their study entitled "Pedagogical Formation Students 'Perception Levels of Self-efficacy in Web Pedagogical Content Knowledge", determined whether or not prospective teachers' perceptions of self-efficacy in web pedagogical content differed on the basis of gender.

On examining prospective teachers' perception levels of self-efficacy according to their department, significant differences were found on all sub-dimensions of the scale in favour of students of science and technology teaching department. This was indeed a logical result which had been expected. Those students' domain knowledge is based on technology. They are involved with technology all through their lives.

\section{Recommendations}

It is necessary to know where to use, how to use and for what purpose to use technology beside having deep technological knowledge in order to be able to integrate technology into the process of teaching [12]. Therefore, prospective teachers should be offered information on how to use the web and web sources in their classes and the opportunities to practice it beside information on the web and web sources.

The fact that technological content knowledge changes faster than other types of content knowledge demonstrate that teachers need more pre-service training in this field [13, 14]. Teachers should be provided with examples for practical applications during pre-service training.

The content for Instructional Technologies and Material Development course offered during teacher training should be renewed in a manner as to include technological equipment and design and use of such equipment.

\section{Notes}

Some parts of this study was presented in WCES (8th World Conference on Educational Sciences) 2016 Spain/Madrid.

\section{REFERENCES}

[1] Lee, M. H., Tsai, C. C., \& Chang, C. Y. Exploring teachers' self-efficacy toward the web pedagogical content knowledge in Taiwan, New York, 2008.

[2] Horzum, M. B. Adaptation of web pedagogical content knowledge survey to Turkish. Elementary Education Online, 10 (1), 257-272, 2011.

[3] Yanpar Yelken, T., Sancar Tokmak, H., Özgelen, S., İncikab1, L. Fen ve Matematik Eğitiminde Teknolojik Pedagojik Alan Bilgisi Temelli Öğretim Tasarımları. Anı Yayıncılık, Ankara, 2013.

[4] Yazar, T. \& Şimşek Ö. Öğretmen adaylarının web pedagojik içerik bilgisinin web destekli öğretim bağlamında incelenmesi, Trakya Üniversitesi Eğitim Fakültesi Dergisi. 5, 2, 207-20, 2015.

[5] Lee, M.H. and Tsai, C.C. Exploring teachers' perceived self-efficacy and technological pedagogical content knowledge with respect to educational use of World Wide Web, Instructional Science: An International Journal of the Learning Sciences, 38 (1), 1-21, 2010.

[6] Lee, M. H., Tsai, C. C., \& Chang, C. Y. Exploring teachers' self-efficacy toward the web pedagogical content knowledge in Taiwan, New York, 2008.

[7] Shulman, L.S. Those who understand: Knowledge growth in teaching. Educational Researcher, 15, 4-14, 1986.

[8] Kavanoz, S., Yüksel, H.G., Özcan, E. Pre-service teachers' self-efficacy perceptions on Web Pedagogical Content Knowledge, Computers and Education, 94-101. 2015.

[9] Akgün, F. Öğretmen adaylarının web pedagojik içerik bilgileri ve öğretmen öz-yeterlik algıları ile ilișkisi, Trakya Üniversitesi Eğitim Fakültesi Dergisi, 3, 1,48-58, 2013.

[10] Kazu, İ. Y.\& Erten, P. Sınıf Öğretmeni Adaylarının Web Pedagojik İçerik Bilgisine İlişkin Görüşleri.10. Ulusal Sınıf Öğretmenliği Eğitim Sempozyumu, Cumhuriyet Üniversitesi,(2011).

[11] Gömleksiz, M. N. \& Fidan, E. K., Pedagojik formasyon programı öğrencilerinin web pedagojik içerik bilgisine ilişkin öz-yeterlik alg1 düzeyleri, Turkish Studies International Periodical For The Languages, Literature and History of Turkish or Turkic, 6, 4, 593-620, 2011.

[12] Mumcu, F.K., Haşlaman, T. ve Usluel, Y.K. Teknolojik Pedagojik Içerik Bilgisi Modeli Çerçevesinde Etkili Teknoloji Entegrasyonunun Göstergeleri, 8th International Educational Technology Conference. Eskişehir: TOJET. 296-299, 2008.

[13] Cox, S. A Conceptual Analysis of Technological Pedagogical Content Knowledge. Ph.D..Thesis, Brigham Young University, 2008. 
[14] Harris, J. \& Hofer, M. Instructional Planning Activity Types as Vehicles for Curriculum-Based TPACK Development, Proceedings of Society for Information Technology and Teacher Education International Conference. Chesapeake, 4087-4095, 2009.

[15] Baris, M. F. European Teachers' Technological Pedagogical Content Knowledge (TPCK) and Educational Use of Web
Technologies. European Journal of Educational Research, 4(4), 149-155, 2015.

[16] Horzum, M. B. The effect of web based instruction on students' web pedagogical content knowledge, course achievement and general course satisfaction, Çukurova University Faculty of Education Journal Vol: 41 No: 1 Page: 25-40, 2012. 